

${ }^{1}$ PTE-BTK, Pszichológia Doktori Iskola

${ }^{2}$ SZTE-BTK Pszichológiai Intézet, Szociál- és Fejlődéspszichológiai Tanszék

\section{Tipikus viselkedésformák és megítélésük feltárása középiskolás osztályközösségekben a normavizsgálat módszerével}

A diákok iskolai viselkedését számos szempont alapján lehet megvizsgálni. A leggyakrabban alkalmazott megközelítést

a tanulmányi eredményesség különbözó mutatói jelentik, amelyek elsósorban az érdemjegyekben és vizsgaeredményekben mutatkoznak meg. Ugyanakkor a hétköznapi iskolai szituációk döntố többsége nem irható le a jegyek és pontértékek segitségével. A diákok viselkedése, órai magatartása, tanulmányi aktivitása és szorgalma összetett rendszert alkot, amelyet számos tényezó együttes múködése alakít. A kutatások ezek közül számos faktor hatását feltárták már, úgy mint az egyéni motiváció (Tóth-Király, Orosz, Dombi, Jagodics, Farkas és Amoura, 2017) vagy a tanárok lelkesedésének percepciója (Evers és Tomic, 2003; Shen és mtsai, 2015). Tanulmányunk célja, hogy a diákok iskolai magatartását befolyásoló ismert tényezók mellett feltárjuk az osztályközösség és azon belül a normák szerepét. Kutatásunk annak vizsgálatára

irányul, hogy azonosithatók-e tipikus, általánosan elóforduló viselkedések a középiskolás osztályokban. Emellett feltárjuk, hogy milyen tartalmúak a leggyakoribb viselkedések, vagyis amelyek a leiró normák alapját jelentik. Valamint foglalkozunk azzal is, hogy ezek a viselkedésformák mennyire elfogadottak egy-egy közösségben egyéni szinten (személyes normák), és a diákok mit gondolnak arról, hogy társaik hogyan viszonyulnak ezekhez (elóíró normák).

\section{A társak szerepe a viselkedés kialakításában}

A társas környezet viselkedésre gyakorolt hatásának vizsgálata a szociálpszichológia egyik régóta kutatott, központi területe. Solomon Asch (1956) klasszikussá vált vonalbecslési kísérletében mutatta ki a társas befolyásolás hatásaként kialakuló nyilvános konformitást. A jelenség kutatása rámutatott arra, hogy ismeretlen személyekből álló csoportokban is létrejöhet a többiek észlelt viselkedéséhez igazodó magatartás, még abban az esetben is, ha az egyén személyes érzelmei, vélekedései, gondolatai ezzel ellenkezőek. A konformitás jelenségével kapcsolatos későbbi vizsgálatok 
továbbá feltárták, hogy nemcsak a többség képes hatást gyakorolni egy csoport viselkedésére, de a konzisztens magatartást mutató kisebbség is tudja befolyásolni a közösség viselkedését, nézeteit (Moscovici, 1977).

A társas befolyásolás kialakulásában fontos szerepe van a többi ember megfigyelésének. Ez alapján alakítjuk ki vélekedésünket, következtetéseinket arról, hogy az adott csoportban mi a követendő viselkedés, mik a csoport elvárásai, normái (Ajzen és Fishbein, 1973). Viselkedésünket azonban nemcsak ezek az elvárások, hanem a saját, korábbi tapasztalatainkon és értékeinken alapuló belső meggyőződéseink is formálják azt illetően, hogy mi magunk mit tartunk helyesnek az adott szituációban (Smith, 1988). Ez a két tényező együttesen határozza meg az egyén viselkedést. Azonban a csoporttagság iránti szükséglet, a valahová tartozás érzésének motívuma arra ösztönzi az embereket, hogy a számukra fontos csoportokban a társaikhoz hasonló módon viselkedjenek, és ezzel párhuzamosan a csoport értékeit belsővé tegyék (Fiske, 2004). Ezért az egyén számára fontos, referenciapontként szolgáló csoportokban nagyobb hatást gyakorolnak a viselkedésre a közösség normái, mert azokkal a személy részben vagy egészben azonosul.

Az iskolai osztály a legtöbb diák számára referenciacsoportot jelent, hiszen a diákok idejük jelentős részét ebben a közösségben töltik. Emellett a serdülők esetében különösen fontos a társas közeg, hiszen ebben az életkorban fejlődéslélektani szempontból is kiemelt szerepe van a kortársakkal való kapcsolatnak (Brown, 2001). A valahová tartozás motívumának kielégítése érdekében különösen fontos, hogy a diák felismerje a csoport normáit, az elvárt viselkedéseket, és ezekhez igazodjon. Ezért van kiemelt jelentősége annak, hogy ezek a normák milyen tartalommal telítődnek. Erre utalnak azok a kutatási eredmények is, amelyek szerint a tinédzserek rizikómagatartása gyakoribb a kortársaik jelenlétében, amit annak tulajdonítanak, hogy az egyéni preferenciákat és hajlamokat felerősítik, esetenként felülírják a társaknak tulajdonított elvárások (Harakeh és de Boer, 2019). Így például a kutatási
Az iskolai osztály a legtöbb diák számára referenciacsoportot jelent, hiszen a diákok idejük jelentôs részét ebben a közösségben töltik. Emellett a serdülók esetében különösen fontos a társas közeg, hiszen ebben az életkorban fejlódéslélektani szempontból is kiemelt szerepe van a kortársakkal való kapcsolatnak (Brown, 2001). A valahová tartozás motivumának kielégitése érdekében különösen fontos, hogy a diák felismerje a csoport normáit, az elvárt viselkedéseket, és ezekhez igazodjon. Ezért van kiemelt jelentósége annak, hogy ezek a normák milyen tartalommal telitódnek. Erre utalnak azok a kutatási eredmények is, amelyek szerint a tinédzserek rizikómagatartása gyakoribb a kortársaik jelenlétében, amit annak tulajdonitanak, hogy az egyéni preferenciákat és hajlamokat felerósítik, esetenként felülírják a társaknak tulajdonitott elvárások (Harakeh és de Boer, 2019). Igy például a kutatási eredmények szerint a diákok személyes meggyózódése mellett az elöíró normák, vagyis a többi osztálytársnak tulajdonitott vélekedések állnak a legerósebb kapcsolatban az agressziv viselkedéssel (Henry és mtsai, 2000). 
eredmények szerint a diákok személyes meggyőződése mellett az elöíró normák, vagyis a többi osztálytársnak tulajdonított vélekedések állnak a legerösebb kapcsolatban az agresszív viselkedéssel (Henry és mtsai, 2000). A tanulmány kiemeli, hogy ezek hatása erösebb, mint pusztán az egyes viselkedések gyakorisága, vagyis a leíró normák.

A csoportok kialakulása során fontos szerepe van a kezdeti időszaknak a tagok által elfogadott viselkedések és értékek kikristályosodásában. Tuckman és Jensen (1977) normaképzésnek nevezi a csoportalakulás folyamatában azt a fázist, amíg a megalakulást követően az új közösségek tagjai közösen létrehozzák saját szabályaikat, értékeiket. Mivel egyes csoportok, például iskolai osztályok akár hosszú évekig is müködhetnek, a tagok viselkedésének alakulásában jelentős szerepe van a normaképzés során létrehozott közös szabály- és értékrendszernek. Ezeknek a közösen elfogadott attitüdöknek és viselkedéseknek fontos funkciója van abban, hogy a csoporttagok számára biztonságos és bejósolható közeget teremtsenek, valamint kifejezhetővé tegyék a csoportidentitást a többi közösségtől való elhatárolódás biztosításával (Feldman, 1984).

Habár a normák szerepét a csoportos és egyéni viselkedés kialakításában számos elmélet hangsúlyozza, eltérő megközelítések léteznek a normák müködésének részleteit illetően (Gibbs, 1965). A tervezett viselkedés elmélete (Madden, Ellen és Ajzen, 1992) interakciót feltételez a társas környezetben észlelt viselkedésre irányuló elvárások és a személyes attitüd között, ami azt implikálja, hogy a csoportos viselkedés megváltoztatásához nem elegendő az egyéni attitüdre hatni, szükség van a tagokra ható normarendszer módosítására is (Salmivalli és Voeten, 2004). Ezek a megfigyelések vezettek a normák különböző típusainak elkülönítéséhez. A leíró normák (descriptive norms) arra vonatkoznak, hogy az egyes magatartásformákkal milyen gyakran találkoznak a csoport tagjai. Az elöíró normák (injunctive norms) ezzel szemben a csoport által helyesnek vagy helytelennek vélt viselkedések megítélésére vonatkoznak (Cialdini, Reno és Kallgren, 1990).

\section{A normák fajtái és feltárásának módszerei}

A normavizsgálat (Smith, 1988) módszerének célja a csoporton belüli különböző szintű normák feltárása. A normák különböző fajtái más-más mértékben ugyan, de együttesen határozzák meg a valós viselkedést. Számos normafelosztási elmélet született, de ezek közül témánk szempontjából a Cialdini és munkatársai (1990) által felállított taxonómia felel meg leginkább. Eszerint a leggyakrabban tapasztalható viselkedések a leíró normákat jelentik. Ezeket a külső szemlélő is megfigyelheti, szisztematikus kódolási eljárással feljegyezhető, számszerüsíthető. Bár az is tény, hogy egyes viselkedések észrevétele a csoporttagok számára nem ugyanannyira valószínü. Lehetnek viselkedések, amelyeket a külső szemlélö gyakorinak vél (pl. a pedagógus), de a diákok nem veszik észre minden esetben, hogy így viselkednek, ezért ritkábbnak ítélik. Ezért a leíró normák valójában szintén nem objektív tények, sokkal inkább percepcióalapú vélekedések, amelyek eltérö eredményt hozhatnak attól függően, hogy ki a megfigyelö. A normák másik formáját az elrendelő normák alkotják. Ezek megközelítése már nem lehetséges megfigyeléssel, ugyanis ezek a meggyőződések arra vonatkoznak, hogy a csoport tagjai mit gondolnak arról, hogy az adott közösség mely viselkedéseket jutalmazza és melyeket szankcionálja. Az így kialakult hitek egységes elemei alakítják az elrendelő normákat. Ezek egy részét a csoport alkalmanként szabályokba foglalja, esetleg le is jegyzi, kvázi szerződésben rögzíti. Azonban a legtöbb esetben ezek az egyének belső meggyőződéseiként jelennek meg, amelyek feltárása már nehezebb feladat. A normák harmadik fajtáját a szubjektív meggyőződések jelentik. A csoport minden tagjának van saját véleménye arról, hogy ő mennyire helyesel, pártol egy viselkedést, vagy esetleg mennyire tartja elítélendőnek, negatívnak. Mindezek alapján látszik, hogy azok a csoportviselkedések lesznek a legerősebbek, amelyek esetében az elrendelő és a szubjektív normák egybeesnek. Hiszen 
ha a tagok maguk is helyesnek tartják az adott viselkedést, és úgy vélik, hogy a csoport többi tagja is így értékeli, akkor ezeket a viselkedéseket valószínübben követik, mint azokat, amelyek esetében nincs ilyen egyetértés. A leíró normákban tehát e két másik normaforma eredője jelenik meg. Az iskolai osztályokban a tanárok a leíró normákat tudják viszonylag könnyen megítélni, hisz látják, hogy melyek a leggyakoribb viselkedések. De azt már nem tudhatják biztosan, hogy ezek mögött mekkora csoportos egyetértés áll. Ennek feltárását szolgálhatja a normavizsgálat.

A normavizsgálat leggyakrabban alkalmazott módszere a kérdőíves adatgyüjtés. A módszer három különböző területet vesz figyelembe. Egyrészt feltárja az adott közösségen belül az egyes viselkedések gyakoriságát, vagyis a leíró normákat. Másrészt a normavizsgálat résztvevői beszámolnak arról, hogy ezekről a viselkedésekről ők maguk hogyan vélekednek, vagyis milyen személyes normák jellemzők a csoport tagjaira. Harmadrészt pedig szerepelnek kérdések arra vonatkozóan, hogy milyen vélekedéseket tulajdonítanak a csoport többségének, vagyis mik a közösség elrendelö normái. A normavizsgálat adatfelvételt megelőző lépése azoknak a magatartásformáknak az összegyüjtése, amelyek rendszeres előfordulásuk okán relevánsak a csoport életében. A Smith (1988) által kidolgozott normavizsgálat továbbfejlesztett változatát Szabó és Labancz (2015) dolgozta ki, kifejezetten iskolai osztályok normarendszerének feltárására, valamint a csoportokban gyakran megfigyelhető „többszörös figyelmen kívül hagyás" (pluralistic ignorance) jelenségének kimutatására (Katz, Allport és Jennes,

A többszörös figyelmen kívül hagyás azt jelenti, hogy a személyes és elrendeló normák között jelentôs különbség van, azaz a diákok egyéni véleménye eltér egyes viselkedések esetében az osztálynak tulajdonított attitúdtól. Ha ez a jelenség fennáll, akkor a diákok olyan normákhoz kezdenek igazodni, amelyek a valóságban sokkal kevésbé elfogadottak egyéni szinten, mint ahogy ók azt egymásról feltételezik. Illetve ennek ellenkezójeként háttérbe szorithatnak bizonyos viselkedéseket, amelyeket önmaguk esetleg helyesnek tartanak, de attól félnek, a többiek nem fogadják el olyan mértékben, mint ók. Ez a jelenség különösen káros olyan esetekben, amikor az iskolai normákkal szemben álló viselkedésekkel kapcsolatban fordul eló (pl. csalás, órai rendbontás, tanulmányok elhanyagolása).

Ilyenkor ugyanis a diákok a vélt csoportnormákhoz igazitják magatartásukat, háttérbe szoritva személyes értékeiket. 1931). A többszörös figyelmen kívül hagyás azt jelenti, hogy a személyes és elrendelő normák között jelentős különbség van, azaz a diákok egyéni véleménye eltér egyes viselkedések esetében az osztálynak tulajdonított attitüdtől. Ha ez a jelenség fennáll, akkor a diákok olyan normákhoz kezdenek igazodni, amelyek a valóságban sokkal kevésbé elfogadottak egyéni szinten, mint ahogy ők azt egymásról feltételezik. Illetve ennek ellenkezőjeként háttérbe szoríthatnak bizonyos viselkedéseket, amelyeket önmaguk esetleg helyesnek tartanak, de attól félnek, a többiek nem fogadják el olyan mértékben, mint ők. Ez a jelenség különösen káros olyan esetekben, amikor az iskolai normákkal szemben álló viselkedésekkel kapcsolatban fordul elő (pl. csalás, órai rendbontás, tanulmányok elhanyagolása). Ilyenkor ugyanis a diákok a vélt csoportnormákhoz igazítják magatartásukat, háttérbe szorítva személyes értékeiket. 


\section{Célkitűzés és hipotézisek}

A kutatás célja a Szabó és Labancz (2015) által kidolgozott normavizsgálati eljárás új szempontú alkalmazása volt. A többszörös figyelmen kívül hagyás jelenségének feltárása mellett (melyre az eredeti vizsgálat irányult) célunk volt azonosítani a korosztályban leggyakrabban előforduló, úgynevezett tipikus viselkedéseket is. Ebben a vizsgálatban tehát nem csak a személyes és észlelt normák közötti eltéréseket tártuk fel, hanem az egyes viselkedések gyakoriságára vonatkozó elemzéseket is végeztünk.

H1: Feltételeztük, hogy a csoportokra sajátosan jellemző viselkedések mellett a normavizsgálat segítségével azonosíthatók olyan iskolai magatartásformák is, amelyek általánosan jellemzőek a középiskolás korosztályra (Smith, 1988).

H2: További kutatási kérdésünk volt, hogy a gyakoriságuk alapján rendszeresen elöforduló, ezért tipikusnak vélt viselkedések közül melyeket észlelik leggyakoribbnak a diákok.

H3: Feltáró faktorelemzés segítségével megvizsgáltuk, hogy a viselkedések a különböző normák alapján milyen nagyobb csoportba rendeződnek.

H4: Feltételeztük, hogy megjelennek olyan magatartásformák, amelyeknél jelentős különbség alakul ki a személyes preferenciák és az osztálytársaknak tulajdonított egyetértés között, azaz több esetben is megnyilvánul a többszörös figyelmen kívül hagyás jelensége (Katz és mtsai, 1931; Szabó és Labancz, 2015).

\section{Módszerek}

\section{Minta és eljárás}

Kutatásunkban 544 középiskolás diák vett részt (241 lány és 295 fiú, 22 „nem válaszolok"). A diákok közül 413 fö kilencedik és 131 fő tizedik évfolyamba járt. A kitöltők átlagéletkora 15,4 év volt (szórás $=0,7$ év).

Az adatfelvétel megkezdése előtt az iskolák intézményvezetői beleegyezésüket adták a kutatás lefolytatásához. A diákok szüleit passzív beleegyező nyilatkozat formájában tájékoztattuk a kutatás céljáról és részleteiről. Azok a diákok, akiknek szülei nem egyeztek bele a gyermekük részvételéhez, nem vettek részt a vizsgálatban. Az adatfelvételre osztályfőnöki órán, papíralapon került sor, illetve ahol a technikai háttér lehetővé tette, online felületen zajlott a kérdőívek kitöltése. A kétféle adatfelvételi módszer alkalmazása nem vezetett eltéréshez az eredmények között. A diákok a kitöltést megelőzően szóban és írásban is tájékoztatást kaptak a kutatás céljáról, és lehetőségük volt dönteni a kérdőívek kitöltéséről. A diákok a kutatásban való részvételért nem részesültek ellenszolgáltatásban. Az adatfelvétel az etikai elöírások figyelembevétele mellett zajlott, a kérdőívek teljes mértékben anonimak voltak. A kutatás folyamatát és a használt módszereket a Pszichológiai Kutatások Egyesült Etikai Bíráló Bizottsága előzetesen jóváhagyta (referenciaszám: 2017/127).

\section{Vizsgálati eszköz: A normavizsgálat}

A normavizsgálat eredeti módszere szerint a csoporton belüli normák feltárásához az első lépés az adott közösségen belüli gyakori és releváns viselkedések azonosítása. Kutatásunkban a Szabó és Labancz (2015) vizsgálatában használt tételekből kiindulva, valamint iskolapszichológusok és pedagógusok személyes tapasztalataira építve hoztunk létre egy olyan, 20 tételből álló viselkedésgyüjteményt, amely gyakorinak vélt iskolai 
magatartásokat tartalmazott. A 20 tétel között 10 pozitív, vagyis az iskolai házirendek által elvárt, és 10 negatív, vagyis az oktatási intézmények szabályaival ütköző viselkedés szerepelt (lásd 1. táblázat). A viselkedéseket összesen három különböző szempont alapján értékelték a diákok. Az első szempont a viselkedés gyakoriságának megítélése volt négyfokú skálán: „Kérlek, hogy jelöld meg, hogy milyen gyakran fordulnak elő az osztályodban az alábbi viselkedések!" ( 1 = Soha, 2 = Időnként, 3 = Gyakran, 4 = Mindig). A második szempont a viselkedésekhez füződő egyéni viszony volt, szintén négyfokú skálán: „Kérlek, hogy jelöld meg, hogy Te mennyire értesz egyet az alábbi viselkedésekkel!" (1 = Egyáltalán nem helyeslem, 2 = Inkább nem helyeslem, 3 = Inkább helyeslem, 4 = Teljesen egyetértek vele). A harmadik esetben az osztálynak tulajdonított vélekedések feltárása volt a kérdőív célja: „Szerinted az osztályod többsége hogyan ítéli meg az alábbi viselkedéseket?" A diákok ebben az esetben is négyfokozatú skálán adhattak választ a kérdésekre ( 1 = Egyáltalán nem helyeslik, 2 = Inkább nem helyeslik, $3=$ Inkább helyeslik, 4 = Teljesen egyetértenek vele).

\section{Eredmények}

A statisztikai elemzésekhez az IBM SPSS 24.0, illetve a Jamovi 0.9.5.12. programcsomagokat használtuk. A vizsgált változók eloszlási jellemzőit Shapiro-Wilk-próbával ellenőriztük a statisztikai elemzést megelőzően. Mivel a normavizsgálatban szereplő tételek esetében nem teljesül a normál eloszlás kritériuma $(\mathrm{p}<0,05)$, ezért a nem-parametrikus statisztikai próbákat használtuk a hipotézisek teszteléséhez.

\section{A viselkedések tipikusságának és gyakoriságának (leiró normák) vizsgálata}

Kutatásunk elsődleges célja a viselkedések tipikusságának vizsgálata volt a középiskolás korosztályban (H1). Ennek érdekében elsőként az egyes magatartásformák gyakoriságát elemeztük abból a szempontból, hogy a minta hány százaléka jelezte, hogy az adott viselkedés soha nem fordul elő az osztályában. A leíró normák megítéléséből látható, hogy a legtöbb viselkedést legalább időnként előfordulónak észlelik a diákok. A húsz magatartásforma közül kettő képez kivételt, amelyek esetében túlsúlyba kerülnek azok a válaszok, amelyek szerint az adott viselkedés „soha” nem fordul elö az osztályban: „Strébernek nevezi a jó tanulókat” és „A jól felelő diákra gúnyos megjegyzést tesz”.

Ugyanakkor, ha megvizsgáljuk, hogy osztályonként milyen a két kritikus viselkedés megítélése, akkor kiderül, hogy mindkettő tipikusnak mondható, de nem egyformán gyakran jelenik meg minden közösségben. A Kruskal-Wallis-teszt szerint ugyanis az adatbázisban azonosítható 18 osztály statisztikailag szignifikáns különbséget mutat a két viselkedés megítélésében: „Strébernek nevezi a jó tanulókat” $\left(\chi_{(17)}^{2}=54,3, p<0,001\right)$, illetve „A jól felelö tanulóra gúnyos megjegyzést tesz” $\left(\chi_{(17)}^{2}=42,7, \mathrm{p}<0,001\right)$. Így ezt a két viselkedést a továbbiakban is tipikusnak tekintettük, és használtuk az elemzés során.

A gyakorisági elemzés arra utal, hogy a kérdőív összeállításakor sikerült olyan viselkedéseket kiválasztani, amelyek jól megragadják a középiskolás osztályokra jellemző magatartásformákat, ugyanakkor alkalmasak az osztályok közötti eltérések feltárására is. Az egyes viselkedések leíró statisztikái alapján a diákok hét pozitív viselkedést észlelnek leggyakoribbnak (H2; lásd 1. táblázat). A pozitív és negatív viselkedések átlagainak összehasonlítása szerint előbbiek gyakorisága statisztikailag szignifikáns mértékben nagyobb a Wilcoxon-próba alapján $(Z=-12,08 ; p<0,001)$. 
Jagodics Balázs - Szabó Éva: Tipikus viselkedésformák és megítélésük feltárása középiskolás osztályközösségekben

1. táblázat. Az egyes viselkedések gyakoriságának megitélése a teljes mintán

\begin{tabular}{lcclcc}
\hline \multicolumn{1}{c}{ Pozitív viselkedések } & Átlag & Szórás & \multicolumn{1}{c}{ Negatív viselkedések } & Átlag & Szórás \\
\hline Elkészíti a házi feladatot. & 3,07 & 0,74 & $\begin{array}{l}\text { Lemásolja valakiéröl a házi } \\
\text { feladatot. }\end{array}$ & 2,59 & 0,94 \\
\hline $\begin{array}{l}\text { Figyel és aktívan dolgozik az } \\
\text { órán. }\end{array}$ & 3,02 & 0,72 & Nem készül az órára. & 2,46 & 0,77 \\
\hline Rendesen készül az órára. & 2,89 & 0,71 & Nem ír házi feladatot. & 2,44 & 0,79 \\
\hline $\begin{array}{l}\text { Kiveszi a részét a } \\
\text { csoportmunkából is. }\end{array}$ & 2,89 & 0,83 & $\begin{array}{l}\text { Súg a másiknak felelés } \\
\text { közben. }\end{array}$ & 2,42 & 0,92 \\
\hline $\begin{array}{l}\text { Megkérdezi a tanártól, ha nem } \\
\text { ért valamit. }\end{array}$ & 2,79 & 0,82 & $\begin{array}{l}\text { Viselkedésével zavarja az } \\
\text { órát. }\end{array}$ & 2,34 & 1,06 \\
\hline $\begin{array}{l}\text { Ötös dolgozatot ír vagy ötösre } \\
\text { felel. }\end{array}$ & 2,71 & 0,72 & $\begin{array}{l}\text { Nem hoz felszerelést az } \\
\text { órára. }\end{array}$ & 2,3 & 0,79 \\
\hline $\begin{array}{l}\text { Jelentkezik, ha a tanár kérdez } \\
\text { valamit. }\end{array}$ & 2,66 & 0,76 & $\begin{array}{l}\text { Puskázik a dolgozatírás } \\
\text { közben. }\end{array}$ & 2,26 & 0,94 \\
\hline $\begin{array}{l}\text { Önként jelentkezik felelni, hogy } \\
\text { javítson a jegyein. }\end{array}$ & 2,33 & 0,77 & Letagadja, hogy volt lecke. & 2,1 & 0,99 \\
\hline $\begin{array}{l}\text { Jelentkezik plusz feladatra. } \\
\text { Elindul egy tanulmányi }\end{array}$ & 2,15 & 0,74 & $\begin{array}{l}\text { Strébernek nevezi a jó } \\
\text { tanulókat. }\end{array}$ & 1,68 & 1 \\
\hline $\begin{array}{l}\text { versenyen. } \\
\text { Összesen: }\end{array}$ & 2,64 & 0,46 & $\begin{array}{l}\text { A jól feleló diákra gúnyos } \\
\text { megjegyzést tesz. }\end{array}$ & 1,5 & 0,82 \\
\hline
\end{tabular}

\section{A különbözö normatípusok struktúrája}

A normák különböző szempontú megítéléseinek szerkezetét feltáró faktorelemzéssel elemeztük (H3). Az elemzéseket Minimum Residual módszerrel végeztük, Oblimin Rotációval. Az értelmezésbe bevont faktorok számát minden esetben párhuzamos elemzéssel határoztuk meg (Horn, 1965), mert ez a módszer lehetővé teszi az egynél kisebb sajátértékü faktorok kiválasztását is (Hayton, Allen és Scarpello, 2004). A faktorok értelmezése során azokat a tételeket vettük figyelembe, amelyek egy faktorhoz tartoztak, és 0,4-nél nagyobb faktortöltést mutattak.

Elsőként a viselkedések gyakoriságára vonatkozó tételek, a leíró normák faktorszerkezetét vizsgáltuk. A változók mind a Kaiser-Meyer-Olkin mutató $(\mathrm{KMO}=0,87)$, mind pedig a Bartlett-féle teszt alapján alkalmasnak bizonyultak a faktorelemzésre $\left(\chi^{2}=3018\right.$, $\mathrm{p}<0,001)$. Az elemzés három faktort határozott meg (2. táblázat). 


\begin{tabular}{|c|c|c|c|}
\hline Viselkedések & 1. faktor & 2. faktor & 3. faktor \\
\hline Rendesen készül az órára. & 0,53 & & \\
\hline Jelentkezik plusz feladatra & 0,52 & & \\
\hline Figyel és aktívan dolgozik az órán. & 0,64 & & \\
\hline Ötös dolgozatot ír vagy ötösre felel. & 0,62 & & \\
\hline Megkérdezi a tanártól, ha nem ért valamit. & 0,48 & & \\
\hline Elkészíti a házi feladatot. & 0,61 & & \\
\hline Jelentkezik, ha a tanár kérdez valamit. & 0,69 & & \\
\hline Elindul egy tanulmányi versenyen. & 0,54 & & \\
\hline Önként jelentkezik felelni, hogy javítson jegyein. & 0,43 & & \\
\hline Kiveszi a részét a csoportmunkából is. & 0,52 & & \\
\hline Letagadja, hogy volt lecke. & & 0,42 & \\
\hline A jól felelő diákra gúnyos megjegyzést tesz. & & 0,64 & \\
\hline Puskázik a dolgozatírás közben. & & 0,53 & \\
\hline Lemásolja valakiéről a házi feladatot. & & 0,43 & \\
\hline Súg a másiknak felelés közben. & & 0,54 & \\
\hline Viselkedésével zavarja az órát. & & 0,47 & \\
\hline Strébernek nevezi a jó tanulókat. & & 0,62 & \\
\hline Nem hoz felszerelést az órára. & & & 0,50 \\
\hline Nem készül az órára. & & & 0,61 \\
\hline Nem ír házi feladatot. & & & 0,72 \\
\hline Sajátérték & 3,92 & 2,67 & 0,48 \\
\hline Megmagyarázott variancia: $38,3 \%$ & $16,17 \%$ & $12,14 \%$ & $9,97 \%$ \\
\hline
\end{tabular}

Az első faktorhoz a pozitív viselkedések tartoznak, míg a negatív viselkedések alkotják a második és a harmadik faktort. A második faktor a csalásra és rendbontó magatartásra utaló viselkedéseket együttesen tartalmazza, míg a harmadik faktor az otthoni felkészülés hiányához kapcsolódik. Az elvégzett nem-parametrikus Friedman-teszt szerint a három faktorba tartozó viselkedések gyakorisága között szignifikáns különbség van $\left(\chi_{(2)}^{2}=204\right.$, $\mathrm{p}<0,001)$. Leggyakoribbak a pozitív viselkedések $(\mathrm{M}=2,64)$, amit a felkészületlenség $(\mathrm{M}=2,41)$ és a csalás-rendbontás magatartásformái követnek $(\mathrm{M}=2,13)$.

A személyes normák vizsgálata eltérő faktorszerkezetet mutatott (H3). A változók mind a Kaiser-Meyer-Olkin-mutató $(\mathrm{KMO}=0,907)$, mind pedig a Bartlett-féle teszt alapján alkalmasnak bizonyultak a faktorelemzésre $\left(\chi^{2}=3869, p<0,001\right)$. Az elemzés alapján a különböző viselkedésformák az egyéni megítélés alapján négy faktorba rendeződnek (3. táblázat). 
Jagodics Balázs - Szabó Éva: Tipikus viselkedésformák és megítélésük feltárása középiskolás osztályközösségekben

3. táblázat. A feltáró faktorelemzés eredményei a személyes normák alapján

\begin{tabular}{|c|c|c|c|c|}
\hline Viselkedések & 1. faktor & 2. faktor & 3. faktor & 4. faktor \\
\hline Rendesen készül az órára. & 0,62 & & & \\
\hline Jelentkezik plusz feladatra & 0,56 & & & \\
\hline Figyel és aktívan dolgozik az órán. & 0,66 & & & \\
\hline Ötös dolgozatot ír vagy ötösre felel. & 0,70 & & & \\
\hline Megkérdezi a tanártól, ha nem ért valamit. & 0,58 & & & \\
\hline Elkészíti a házi feladatot. & 0,65 & & & \\
\hline Jelentkezik, ha a tanár kérdez valamit. & 0,69 & & & \\
\hline Elindul egy tanulmányi versenyen. & 0,67 & & & \\
\hline $\begin{array}{l}\text { Önként jelentkezik felelni, hogy javítson } \\
\text { jegyein. }\end{array}$ & 0,74 & & & \\
\hline Kiveszi a részét a csoportmunkából is. & 0,56 & & & \\
\hline Letagadja, hogy volt lecke. & & 0,56 & & \\
\hline Puskázik a dolgozatírás közben. & & 0,70 & & \\
\hline Lemásolja valakiéről a házi feladatot. & & 0,68 & & \\
\hline Súg a másiknak felelés közben. & & 0,71 & & \\
\hline A jól felelő diákra gúnyos megjegyzést tesz. & & & 0,71 & \\
\hline Viselkedésével zavarja az órát. & & & 0,50 & \\
\hline Strébernek nevezi a jó tanulókat. & & & 0,77 & \\
\hline Nem hoz felszerelést az órára. & & & & 0,62 \\
\hline Nem készül az órára. & & & & 0,63 \\
\hline Nem ír házi feladatot. & & & & 0,58 \\
\hline Sajátérték & 5,46 & 2,26 & 0,49 & 0,38 \\
\hline Megmagyarázott variancia: $48,0 \%$ & $21,7 \%$ & $10,72 \%$ & $8,19 \%$ & $7,42 \%$ \\
\hline
\end{tabular}

A személyes normák esetében négy faktorba sorolhatók a vizsgált viselkedésekkel kapcsolatos attitüdök. Az első faktor ebben az esetben is a pozitív viselkedéseket tartalmazza, míg a fennmaradó három faktorba kerültek a negatív magatartásformák. A második faktor az iskolai csalás különböző formáit tartalmazza, míg a harmadik faktorba a rendbontó, másokat megbántó viselkedések kerültek. A negyedik faktor ebben az esetben is az otthoni felkészülés hiányához kapcsolódik. Az elvégzett nem-parametrikus Friedman-teszt szerint a négy faktorba tartozó viselkedések személyes megítélése között szignifikáns különbség van $\left(\chi_{(3)}^{2}=1124, \mathrm{p}<0,001\right)$. A diákok leginkább a pozitív viselkedésekkel értenek egyet $(M=3,44)$, amelyet a csalás különböző formái $(M=2,23)$, a felkészületlenség $(M=1,75)$. és a rendbontással összefüggő magatartásformák követnek $(\mathrm{M}=1,39)$.

Az elöíró normák, vagyis az osztály észlelt vélekedése esetében hasonló faktorstruktúrát tártak fel az elemzések. A változók mind a Kaiser-Meyer-Olkin-mutató $(\mathrm{KMO}=$ 0,90), mind pedig a Bartlett-féle teszt alapján alkalmasnak bizonyult a faktorelemzésre $\left(\chi^{2}=4287, p<0,001\right)$. Az elemzés alapján a különböző viselkedésformák az osztály észlelt vélekedése alapján négy faktorba rendeződnek (4. táblázat). 
4. táblázat. A feltáró faktorelemzés eredményei az elöiró normák alapján

\begin{tabular}{|c|c|c|c|c|}
\hline Viselkedések & 1. faktor & 2. faktor & 3. faktor & 4. faktor \\
\hline Rendesen készül az órára. & 0,60 & & & \\
\hline Jelentkezik plusz feladatra & 0,70 & & & \\
\hline Figyel és aktívan dolgozik az órán. & 0,71 & & & \\
\hline Ötös dolgozatot ír vagy ötösre felel. & 0,71 & & & \\
\hline Megkérdezi a tanártól, ha nem ért valamit. & 0,55 & & & \\
\hline Elkészíti a házi feladatot. & 0,66 & & & \\
\hline Jelentkezik, ha a tanár kérdez valamit. & 0,67 & & & \\
\hline Elindul egy tanulmányi versenyen. & 0,67 & & & \\
\hline $\begin{array}{l}\text { Önként jelentkezik felelni, hogy javítson } \\
\text { jegyein. }\end{array}$ & 0,59 & & & \\
\hline Kiveszi a részét a csoportmunkából is. & 0,55 & & & \\
\hline Letagadja, hogy volt lecke & & 0,54 & & \\
\hline Puskázik a dolgozatírás közben. & & 0,80 & & \\
\hline Lemásolja valakiéről a házi feladatot. & & 0,75 & & \\
\hline Súg a másiknak felelés közben. & & 0,71 & & \\
\hline A jól felelő diákra gúnyos megjegyzést tesz. & & & 0,76 & \\
\hline Viselkedésével zavarja az órát. & & & 0,40 & \\
\hline Strébernek nevezi a jó tanulókat. & & & 0,82 & \\
\hline Nem hoz felszerelést az órára. & & & & 0,50 \\
\hline Nem készül az órára. & & & & 0,50 \\
\hline Nem ír házi feladatot. & & & & 0,54 \\
\hline Sajátérték & 5,82 & 2,34 & 0,43 & 0,32 \\
\hline Megmagyarázott variancia: 49,5 \% & $21,97 \%$ & $12,0 \%$ & $9,26 !$ & $6,24 \%$ \\
\hline
\end{tabular}

Az észlelt normák szempontjából a viselkedések ugyanúgy négy faktorba rendeződnek, mint a személyes vélekedések esetében. Az első faktorba a pozitív viselkedések tartoznak, és a fennmaradó három faktort alkotják a negatív magatartásformák. A második faktor az iskolai csalás különböző formáit tartalmazza, míg a harmadik faktorba a rendbontó, másokat megbántó viselkedések kerültek. A negyedik faktor ebben az esetben is a felkészületlenséghez kapcsolódik. Az elvégzett nem-parametrikus Friedman-teszt szerint a négy faktorba tartozó viselkedések között szignifikáns különbség van az osztálynak tulajdonított vélekedés szempontjából $\left(\chi_{(3)}^{2}=900, p<0,001\right)$. A diákok szerint osztálytársaik leginkább a pozitív viselkedésekkel értenek egyet $(\mathrm{M}=3,21)$, amit a csalás különböző formái $(M=2,50)$, a felkészületlenség $(M=1,99)$ és a rendbontással összefüggő magatartásformák követnek $(\mathrm{M}=1,68)$. 


\section{A normák különbözö megitélésének összefüggései}

A személyes és elrendelő normák közötti különbségek feltárására (H4) nem-parametrikus Wilcoxon-próbát használtunk, mert a változók nem tettek eleget a normáleloszlás kritériumának a Saphiro-Wilk-próba alapján $(\mathrm{p}>0,05)$. Az elemzések eredményei megerősítik második hipotézisünket a normaeltéréseket illetően. A Wilcoxon-próba szerint ugyanis statisztikailag jelentős különbség van a pozitív viselkedésekkel kapcsolatos személyes és elrendelő normák között $(Z=-12,90 ; p<0,001)$. Az eredmények szerint a tanulók személyes attitüdje támogatóbb a pozitív viselkedések iránt $(\mathrm{M}=3,44)$, mint amit társaik vélekedéséről feltételeznek $(\mathrm{M}=3,21)$. A negatív viselkedések esetében szintén különbség van a személyes és az elrendelö normák között a csalásra $(Z=-10,12$; $p<0,001)$, a rendbontásra $(Z=-10,66 ; p<0,001)$ és a felkészületlenségre $(Z=-9,12 ; p$ $<0,001)$ vonatkozó magatartásformáknál egyaránt. A három negatív viselkedésmintázattal szemben a diákok személyes vélekedése elutasítóbb, mint az osztálytársaik esetében feltételezett attitüd (5. táblázat).

5. táblázat. Az egyes viselkedéstipusok megitélése a személyes és elrendelö normák alapján

\begin{tabular}{|c|c|c|c|c|}
\hline & \multicolumn{4}{|c|}{ Átlag } \\
\hline & & $\begin{array}{c}\text { Személyes } \\
\text { norma }\end{array}$ & $\begin{array}{l}\text { Elöíró } \\
\text { norma }\end{array}$ & Wilcoxon-próba (p) \\
\hline \multicolumn{2}{|l|}{ Pozitív viselkedések } & 3,44 & 3,21 & $<0,001$ \\
\hline \multirow{3}{*}{ Negatív viselkedések } & Csalás & 2,22 & 2,50 & $<0,001$ \\
\hline & Rendbontás & 1,38 & 1,68 & $<0,001$ \\
\hline & Felkészületlenség & 1,75 & 1,99 & $<0,001$ \\
\hline
\end{tabular}

A normák különböző szempontú megítélése közötti összefüggéseket a továbbiakban Spearman-féle korrelációelemzéssel vizsgáltuk. A személyes és elrendelő normák szignifikáns, erős kapcsolatban állnak egymással a pozitív viselkedések $\left(\mathrm{r}_{(544)}=0,628 ; \mathrm{p}<\right.$ $0,001)$ és a csalás $\left(\mathrm{r}_{(544)}=0,61 ; \mathrm{p}<0,001\right)$ esetében. A rendbontás $\left(\mathrm{r}_{(544)}=0,464 ; \mathrm{p}<\right.$ $0,001)$ és a felkészületlenség $\left(\mathrm{r}_{(544)}=0,42 ; \mathrm{p}<0,001\right)$ tekintetében statisztikailag jelentös közepes, illetve gyenge korreláció figyelhető meg a személyes és elrendelő normák között (6. táblázat).

6. táblázat. A személyes és elrendelő normák megitélése közötti kapcsolat (Spearman-féle korreláció)

\begin{tabular}{lcccc}
\hline \multirow{2}{*}{ Személyes normák } & Pozitív viselkedések & Csalás & Rendbontás & Felkészületlenség \\
\hline Pozitív viselkedések & $0,62^{* *}$ & $-0,02$ & $-0,19^{* *}$ & $-0,14^{* *}$ \\
\hline Csalás & $-0,12^{*}$ & $0,61^{* *}$ & $0,31^{* *}$ & $0,35^{* *}$ \\
\hline Rendbontás & $-0,31^{* *}$ & $0,26^{* *}$ & $0,46^{* *}$ & $0,26^{* *}$ \\
\hline Felkészületlenség & $-0,16^{* *}$ & $0,28^{* *}$ & $0,22^{* *}$ & $0,42^{* *}$ \\
\hline
\end{tabular}

$* \mathrm{p}<0,05 ; *$ p $<0,001$ 


\section{Következtetések, megvitatás}

Kutatásunk célja az volt, hogy a normavizsgálat módszerével (Smith, 1988; Szabó és Labancz, 2015) azonosítsunk olyan iskolai viselkedéseket, amelyek általánosságban jellemzik a 14-15 éves korosztályt. A leíró normák elemzése alátámasztotta, hogy az általunk választott 20 viselkedés megfelel ennek a követelménynek, hiszen a kitöltők egyetlen viselkedés esetében sem jelölték, hogy az adott viselkedés soha nem fordul elő. Emellett az is látszik, hogy bár a viselkedések a gyakoriságuknál fogva tipikusak, mégsem mondható, hogy minden osztályban egyenlő mértékben fordulnak elő. Tehát az általunk választott 20 tétel egyaránt alkalmas a tipikus viselkedések megragadására és az osztályok közötti eltérések vizsgálatára is. A faktorelemzés alapján a viselkedések a diákok gondolkodásában csoportokba rendeződnek. A pozitív viselkedések és a negatívak elkülönülnek, és a negatívak ezen belül is további alcsoportokba rendeződnek. A legygyakoribbnak a pozitív viselkedéseket tartják a diákok, amelyeket a felkészületlenségre és a csalásra-rendbontásra vonatkozó viselkedésformák követnek. A pozitív viselkedések gyakoribbnak észlelése nemcsak a valós szituációt tükrözheti, utalhat csoportorientált elfogultságra is az észlelésben, ami az énkiemelés motívumának csoportszintű megnyilvánulása (Fiske, 2004), valamint a saját csoport viselkedésének megítélésével kapcsolatos torzítás (ingroup bias) megnyilvánulása (Brewer, 1999). A személyes normák elemzése négy faktort tárt fel. Ebben az esetben is egy csoportba tartoznak a pozitív viselkedések, míg a negatív magatartásformák három kategória szerint különülnek el: csalás, órai rendbontás és felkészületlenség. Ez arra utal, hogy a diákok a helyes magatartásformákat kevésbé differenciáltan észlelik, mint a negatívakat, ami talán összefügghet azzal, hogy a negatív viselkedésekre differenciáltabb visszajelzést kapnak tanáraiktól is. Ennek megfelelően a ,jó" viselkedés megítélését egységes helyeslés jellemzi, míg a negatív viselkedésformáknál erősebben jelennek meg az egyéni különbségek, erre utalnak a negatív viselkedések megítélésénél megfigyelhető magasabb relatív szórásértékek is.

A normavizsgálat eredeti módszere szerint (Smith, 1988) minden csoportban szükséges feltárni az adott közegre jellemző viselkedésmintákat, és ezután lehet értékelni az egyes magatartásformákat a különböző megítélések tekintetében. Ugyanakkor jelen vizsgálat rámutatott arra, hogy az olyan jól körülhatárolt társas környezetben, mint az iskola, kialakulnak olyan jellemző viselkedésformák, amelyek az adott szervezet minden csoportjában megjelennek valamilyen mértékben. A vizsgálatunkban szereplő húsz viselkedésforma ebből a szempontból „univerzálisnak” látszik, legalábbis a mintában szereplő középiskolák kilencedik és tizedik évfolyamában. Ezt támasztja alá, hogy a viselkedések gyakoriságának megítélésekor kis szórásértékeket kaptunk, és egyetlen esetben sem jelent meg padlóhatás, vagyis egyik magatartásformát sem tartották rendkívül ritkának a diákok.

Amellett, hogy a mintán belül sikerült azonosítani a gyakoriságuk alapján tipikus viselkedéseket, az osztályok közötti összehasonlító vizsgálatok rámutattak arra is, hogy az egyes viselkedések észlelése és elfogadottsága jelentősen különbözhet a csoportok között, ami a későbbiekben lehetővé teszi intézmények vagy osztályok összehasonlítását is. Továbbá az egységes viselkedéskészlet alkalmazása nemcsak a csoportok elkülönítésére, de az adott osztályon belüli változások nyomon követésére is alkalmassá teszi a mérőeszközt. A kutatás fontos eredménye, hogy rámutatott az iskolai osztályokban is gyakran megjelenö többszörös figyelmen kívül hagyás (pluralistic ignorance) jelenségére (Katz és mtsai, 1931). Az egyéni vélekedések és az elrendelő normák eltéréseinek megbeszélése az osztály tagjaival segíthet abban, hogy ezek a normákat befolyásoló téves feltevések megszünjenek, és erőteljesebben érvényre jussanak a valódi személyes meggyőződések a csoport viselkedésében. További hasznos gyakorlati alkalmazása 
lehet annak segítése, hogy az iskolai munkát zavaró viselkedések forrását azonosítani lehessen. Mások viselkedésének magyarázatakor különböző stratégiákat alkalmazunk. Belső attribúcióról van szó, ha személyre jellemző tulajdonságokat, személyiségvonásokat teszünk felelőssé a viselkedésért. Külső attribúció alkalmazása történik, ha a kontextus hatásának tulajdonítjuk az egyén magatartását (Heider, 1958; Weiner, 2010). Iskolai körülmények között a pedagógusok szempontjából döntő jelentősége van annak, hogy az órát zavaró viselkedését a diák személyes attitüdjének, vagy a társas környezet hatásának tulajdonítja-e. Ez a negatív viselkedések esetében azért lényeges, mert ha egy viselkedését a diák inkább a társas környezet hatásának tulajdonítja, akkor kevésbé érzi, hogy képes azt befolyásolni, megváltoztatni, kisebb mértékben érez felelösséget vele kapcsolatban.

A reprezentativitás hiánya és a minta elemszáma miatt jelen vizsgálat eredményei természetesen nem általánosíthatók minden hazai oktatási intézményre. Ennek ellenére a kutatás rámutatott arra, hogy a normavizsgálat módszere nem csak a tudományos vizsgálatokban, hanem az oktatási intézmények napi gyakorlatában is hasznos méröeszköz lehet. Elsősorban azokban az iskolákban segítheti az összetartó, motivált és az iskola céljai iránt elkötelezett közösségek kialakítását, ahol iskolapszichológus is segíti a pedagógiai munkát. Az egyes osztályokra jellemző normák felmérése hozzájárulhat a csoportban zajló folyamat megértéséhez. Emellett a normavizsgálat jól kombinálható más csoportfókuszú módszerek alkalmazásával, például a többszempontú szociometriai vizsgálattal (Mérei, 2006).

\section{Irodalom}

Ajzen, I. \& Fishbein, M. (1973). Attitudinal and normative variables as predictors of specific behavior. Journal of Personality and Social Psychology, 27(1), 41-57. DOI: $10.1037 / \mathrm{h} 0034440$

Asch, S. E. (1956). Studies of independence and conformity: A minority of one against a unanimous majority. Psychological Monographs: General and Applied, 70(9), 1-70. DOI: 10.1037/h0093718

Brewer, M. B. (1999). A saját csoport iránti elfogultság és a minimális csoportközi helyzet: egy kognitív motivációs elemzés. In Hunyady György, Hamilton, D. L. és Lan Anh, N. L. (szerk.), A csoportok percepciója. Budapest: Akadémiai Kiadó. 49-72.

Brown, R. (2001). Group processes: dynamics within and between groups. (2nd ed). Oxford, UK ; Malden, Mass: Blackwell Publishers. DOI: $10.1002 / 9781118719244$

Cialdini, R. B., Reno, R. R. \& Kallgren, C. A. (1990). A focus theory of normative conduct: Recycling the concept of norms to reduce littering in public places. Journal of Personality and Social Psychology, 58(6), 1015-1026. DOI: 10.1037//0022-3514.58.6.1015

Evers, W. J. G. \& Tomic, W. (2003). Students' Perceptions of the Incidence of Burn-out among Their Teachers. Research in Education, 69(1), 1-15. DOI: 10.7227/rie.69.1

Feldman, D. C. (1984). The development and enforcement of groupnorms. Academy of Management Review, 9(1), 47-53. DOI: 10.5465/amr.1984.4277934
Fiske, S. T. (2004). Social beings: core motives in social psychology. Hoboken, NJ: Wiley.

Gibbs, J. P. (1965). Norms: The problem of definition and classification. American Journal of Sociology, 70(5), 586-594. DOI: 10.1086/223933

Harakeh, Z. \& de Boer, A. (2019). The effect of active and passive peer encouragement on adolescent risk-taking. Journal of Adolescence, 71, 10-17. DOI: 10.1016/j.adolescence.2018.12.004

Hayton, J. C., Allen, D. G. \& Scarpello, V. (2004). Factor Retention Decisions in Exploratory Factor Analysis: a Tutorial on Parallel Analysis. Organizational Research Methods, 7(2), 191-205. DOI: 10.1177/1094428104263675

Heider, F. (1958). The Psychology of Interpersonal Relations. New York: Wiley. DOI: 10.1037/10628000

Henry, D., Guerra, N., Huesmann, R., Tolan, P., VanAcker, R. \& Eron, L. (2000). Normative Influences on Aggression in Urban Elementary School Classrooms. American Journal of Community Psychology, 28(1), 59-81. DOI: 10.1023/a:1005142429725

Horn, J. L. (1965). A rationale and test for the number of factors in factor analysis. Psychometrika, 32, 179-185. DOI: 10.1007/bf02289447

Katz, D., Allport, F. H. \& Jennes, M. B. (1931). Students' attitudes; A report of the Syracuse University reaction study. Syracuse: Craftsman. 
Madden, T. J., Ellen, P. S. \& Ajzen, I. (1992). A comparison of thetheory of plannedbehavior and thetheory of reasonedaction. Personality and Social Psychology Bulletin, 18(1), 3-9. DOI: $10.1177 / 0146167292181001$

Mérei Ferenc (2006). Közösségek rejtett hálózata Szociometriai értelmezés. Budapest: Osiris.

Moscovici, S. (1977). Social influence and social change. London: Academic Press.

Salmivalli, I. \& Voeten, M. (2004). Connections between attitudes, group norms, and behaviour in bullying situations. International Journal of Behavioral Development, 28(3), 246-258. DOI: $10.1080 / 01650250344000488$

Shen, B., McCaughtry, N., Martin, J., Garn, A., Kulik, N. \& Fahlman, M. (2015). The relationship between teacher burnout and student motivation. British Journal of Educational Psychology, 85(4), 519-532. DOI: 10.1111/bjep.12089

Smith, P. B. (1988). Norms and roles in the small group. In Doing Social Psychology. Leicester:
The British Psychological Society. 291-308. DOI: 10.1017/cbo9780511659898.016

Szabó Éva és Labancz Ágnes (2015). „Én nem helyeslem, de a többiek biztosan". Normák és vélt-normák müködése és mérése az iskolai osztályokban. In Szociálpszichológiai tanulmányok a Szociál- és Munkapszichológiai Tanszék fennállásának 25. évfordulójára. Debrecen: Debreceni Egyetem. 77-97.

Tóth-Király, I., Orosz, G., Dombi, E., Jagodics, B., Farkas, D. \& Amoura, C. (2017). Cross-cultural comparative examination of the Academic Motivation Scale using exploratory structural equation modeling. Personality and Individual Differences, 106, 130-135. DOI: 10.1016/j.paid.2016.10.048

Tuckman, B. W. \& Jensen, M. A. C. (1977). Stages of small-group development revisited. Group \& Organization Studies, 2(4), 419-427. DOI: 10.1177/105960117700200404

Weiner, B. (2010). Attribution Theory. In International Encyclopedia of Education. 558-563. DOI: 10.1016/b978-0-08-044894-7.00600-x

\title{
Köszönetnyilvánítás, támogatás:
}

Jagodics Balázs a kutatáshoz az Emberi Erőforrások Minisztériuma ÚNKP-18-3 Kódszámú Új Nemzeti Kiválóság Programjának támogatásában részesült.

\begin{abstract}
Absztrakt
A diákok viselkedési problémái számos módon akadályozzák az iskolában folyó munkát. Emiatt különösen fontos feltérképezni azokat a tényezőket, amik befolyásolhatják egy osztály tanulóinak magatartását. A viselkedéses problémák hátterében nemcsak egyéni motiválatlanság állhat, hanem megjelenhetnek a társas környezet hatására is. Kutatásunk célja annak vizsgálata volt, hogy a társas befolyásolás hogyan hozható összefüggésbe a diákok viselkedésével. Középiskolás diákok körében $(\mathrm{N}=544$ fö) a normavizsgálat módszerével tártuk fel a leggyakoribb iskolai viselkedéseket, illetve a tanulók ezekhez füződő személyes attitüdjeit. Emellett megvizsgáltuk azt is, hogy a diákok mit gondolnak osztálytársaik vélekedéseiröl az egyes magatartásformákkal kapcsolatban (elöíró normák). A leíró normák három csoportját sikerült azonosítanunk feltáró faktorelemzés segítségével: az iskola szempontjából pozitív viselkedések egy faktorba sorolódtak, és egyben ezek a legygyakoribbak is, amelyeket a felkészületlenség és a csalás-rendbontás követ. A személyes normák alapján a viselkedések négy faktorba sorolhatók: a pozitív magatartásformák itt is egy faktort alkotnak, mellettük a csalás, a felkészületlenség és az órai rendbontás jelenik meg. Ugyanez a struktúra jellemző az elöíró normákkal kapcsolatban is. Az eredmények alapján a személyes és elöíró normák közepesen erős együtt járást mutatnak, ami arra utal, hogy a diákok egyéni normarendszere igazodik az osztálytársaiknál látottakhoz. Ugyanakkor a személyes és elöíró normák összehasonlítása rámutat arra, hogy jelentős pontatlanságok is lehetnek az osztálytársak attitüdjeinek megítélésében. Kutatási eredményeink hozzájárulhatnak az iskolai magatartási problémák kialakulásának jobb megértéséhez, ami különböző módszerek kidolgozásával, például közösségépítő foglalkozások tervezésével a megoldásukat is elősegítheti.
\end{abstract}

